J. Asiat. Soc. Bangladesh, Sci. 40(2): 173-178, December 2014

\title{
CHANGES IN BIOCHEMICAL COMPONENTS OF RICE FOLLOWING NAA APPLICATION
}

\author{
NARGIS JAHAN ${ }^{1}$ AND A. M. M. GOLAM ADAM \\ Plant Physiology Laboratory, Department of Botany, University of Dhaka, \\ Dhaka-1000, Bangladesh
}

\begin{abstract}
An investigation on the effect of Naphthalene acetic acid (NAA) on the changes of biochemical components of two varieties of rice (Oryza sativa L.), BRRI dhan 29 and BRRI dhan 50 was carried out. Two concentrations of NAA, 100 and 200 ppm were used as foliar spray. In BRRI dhan 29 , significant increases in chlorophyll a and chlorophyll b contents of leaf were observed due to both the treatments at the flowering stage, whereas, carotenoids at the grain filling stage only. But in BRRI dhan 50, the total leaf pigments decreased at the flowering and grain filling stage, but was significant in case of chlorophyll a at the flowering stage. Significant increases in protein content of leaf were recorded at the tillering and flowering stage of BRRI dhan 29 following $100 \mathrm{ppm}$ NAA treatment. In BRRI dhan 50, the only significant increase was recorded at grain filling stage due to $200 \mathrm{ppm}$ NAA treatment. In both the varieties carbohydrates, protein, fat, and energy content of grain increased due to both the treatments and the maximum increase in all the cases was recorded due to $100 \mathrm{ppm}$ NAA treatment. Ash and moisture content of grain reduced following both the treatments in both the varieties, the maximum reduction was due to 100 ppm NAA treatment.
\end{abstract}

Key words: Rice, NAA, Foliar application, Biochemical components

\section{Introduction}

Rice (Oryza sativa L.) is the most important staple food with regards to human nutrition and caloric intake. It's endosperm is rich in carbohydrates and contains a fair amount of digestible protein (FAO 1993). Hulled rice contains approximately 10.9 - $13.8 \%$ water; 5.5 - $9.3 \%$ protein; 0.6 - $2.6 \%$ fat; 73.4 - $80.8 \%$ carbohydrate; 0.2 - 1.0 fibre and 0.8 $2.0 \%$ ash (Purseglove 1975). Plant growth regulators can be applied directly to plants in various ways to alter life processes and structure or both in some beneficial way, so as to improve quality or to facilitate harvesting. Studies conducted elsewhere reported about the beneficial effects of NAA on growth, yield, physiological and biochemical aspect of different cereal plants including rice (Chaudhuri et al. 1980, Sing and Gill 1985, Orsi and Tallarico 1983, Muthukumar et al. 2005). In Bangladesh, reports regarding the effect of NAA on growth, yield and yield attributes of rice are available. Adam and Jahan (2011) reported that in BRRI dhan 29, yield and yield attributes increased following 100 and 200 ppm NAA application, whereas, most of the yield parameters decreased in BRRI dhan

\footnotetext{
${ }^{1}$ Corresponding author: Email: jahan.nargis@yahoo.com
} 
50. In a comparative growth analysis, Jahan and Adam (2011) observed differences in responses between two varieties of rice and between the two concentrations of NAA where, better stimulation was due to $100 \mathrm{ppm}$. The favourable effect of NAA in enhancing nutrient uptake by rice is also reported (Adam et al. 2012). As no report is yet available on the effect of NAA on changes of biochemical components of any varieties of rice, the present research work was undertaken to do the same.

\section{Materials and Methods}

A pot experiment was conducted at the research field of the Department of Botany, University of Dhaka using two varieties of rice where, BRRI dhan 29 is a high yielding variety and BRRI dhan 50 is a high yielding aromatic variety. BRRI dhan 50 is commonly known as Banglamoti rice and the grain size of this variety is better than Indian and Pakistani 'basmati rice'. Seeds collected from BRRI, sterilized with $0.5 \%$ $\mathrm{Ca}(\mathrm{OCl})_{2}$ solution and then thoroughly washed with distilled water were sown on November 7, 2009. The experiment was laid out in RCBD with three replications, each having 12 pots $(3 \times 12 \times 2=72)$. Analysis of the experimental soil got down by the Soil Water and Environment Science Department, Dhaka University indicated optimum level of nitrogen and potassium and high level of phosphorus (Fertilizer Recommendation Guide 2005). Each pot was filled with $9.0 \mathrm{~kg}$ air dried soil mixed with $0.5 \mathrm{~kg}$ cow-dung. Seedlings were transplanted to experimental pots at the age of 36 days after sowing (DAS). Before transplanting the seedlings, $2 \mathrm{~g}$ of gypsum was also added in each pot. Urea as a source of nitrogen was applied twice at the rate of $1 \mathrm{~g}$ per pot at 20 and 50 days after transplanting (DAT). Weeding and irrigation were done as per necessity. The experiment comprised of three treatments: $T_{0}=$ Distilled water (Control), $T_{1}=100 \mathrm{ppm}$ NAA, and $T_{2}=200 \mathrm{ppm}$ NAA. Treatments were applied as foliar spray at 57 DAT. Pigments and protein contents of leaves were determined for each treatment at 3 stages viz. tillering ( 72 days), flowering ( 95 days) and grain filling (118 days). Third leaf from the tip was used for analysis of pigments and protein content at all the three stages. The analysis of pigments was determined by using specific absorption co-efficient of Mckinney (1940) and the formulae of Maclachalan and Zalik (1963). The amounts of carotenoids were determined by the equation of von Wettstein (1957). The method of Lowry et al. (1951) was employed to determine the leaf protein. Carbohydrate, protein, fat, ash, moisture and energy content of grain were determined according to Anonymous (1976). Data were analyzed statistically (Steel and Torrie 1960) and treatment means were compared by LSD test at $5 \%$ level of significance.

\section{Results and Discussion}

Results presented in Tables 1 reveal that pigment content of leaf varied both significantly and insignificantly at different stages in BRRI dhan 29. At the tillering stage, pigment contents (chlorophyll a, chlorophyll b and carotenoids) of leaf decreased due to both 
$\mathrm{NAA}_{100}$ and $\mathrm{NAA}_{200}$ treatments. However, at the flowering and grain filling stage pigment contents of leaf increased due to both the treatments. Significant variations were observed in case of chlorophyll a and chlorophyll $b$ at the flowering stage and carotenoids content at grain filling stage. The decrease in pigment content at the tillering stage might be attributed to the inability of plant to keep pace with the enhanced leaf expansion and new tiller production. The rate at which chlorophyll synthesis increased might be lower than that of leaf area leading to a net decrease in the chlorophyll content per area. In BRRI dhan 50 , pigment content of leaf was positively influenced only at tillering stage and the variation among the treatments was insignificant (Table 2). The maximum amount of pigment content (chlorophyll a, chlorophyll $\mathrm{b}$ and carotenoids) was obtained from $\mathrm{NAA}_{200}$ treatment whereas, chlorophyll $b$ and carotenoids content was same as in control due to $\mathrm{NAA}_{100}$ treatment. At the flowering and grain filling stage, pigment content of leaf decreased due to both the treatments. The decrease in pigment content may be due to increase in the number of older leaves which lost photosynthetic activity. This is also because pigments breakdown after certain growth stage.

Table 1. Effect of NAA on pigment content of leaf $(\mathrm{mg} / \mathrm{g}$ fresh weight) of BRRI dhan 29.

\begin{tabular}{lccccccccc}
\hline & \multicolumn{3}{c}{ Tillering (72 days) } & \multicolumn{3}{c}{ Flowering (95 days) } & \multicolumn{3}{c}{ Grain filling (118 days) } \\
\cline { 2 - 10 } Treatments & Chl. a & Chl. b & Carotenoids & Chl. a & Chl. b & Carotenoids & Chl. a & Chl. b Carotenoids \\
\hline NAA $_{0}$ & 0.39 & $0.66 \mathrm{a}$ & 2.15 & $0.20 \mathrm{c}$ & $0.22 \mathrm{~b}$ & 1.50 & 0.16 & 0.30 & $1.71 \mathrm{~b}$ \\
NAA $_{100}$ & 0.38 & $0.59 \mathrm{a}$ & 2.08 & $0.23 \mathrm{~b}$ & $0.37 \mathrm{a}$ & 1.59 & 0.20 & 0.34 & $1.83 \mathrm{a}$ \\
NAA $_{100}$ & 0.36 & $0.55 \mathrm{ab}$ & 2.02 & $0.27 \mathrm{a}$ & $0.40 \mathrm{a}$ & 1.75 & 0.17 & 0.31 & $1.62 \mathrm{c}$ \\
$\mathrm{CV}(\%)$ & 5.20 & 10.80 & 3.20 & 14.70 & 22.30 & 10.50 & 16.90 & 7.90 & 5.50 \\
LSD $(0.05)$ & NS & 0.09 & NS & 0.04 & 0.05 & NS & NS & NS & 0.11 \\
& & & & & & & & & \\
\hline
\end{tabular}

Mean in a vertical column followed by same letter do not differ significantly at $5 \%$ level.

Table 2. Effect of NAA on pigment content of leaf ( $\mathrm{mg} / \mathrm{g}$ fresh weight) of BRRI dhan 50 .

\begin{tabular}{|c|c|c|c|c|c|c|c|c|c|}
\hline \multirow[b]{2}{*}{ Treatments } & \multicolumn{3}{|c|}{ Tilllering ( 72 days) } & \multicolumn{3}{|c|}{ Flowering ( 95 days) } & \multicolumn{3}{|c|}{ Grain filling (118 days) } \\
\hline & Chl. a & Chl. b & Carotenoids & Chl. a & Chl. b & $\begin{array}{l}\text { Caroten } \\
\text { oids }\end{array}$ & & & $\begin{array}{l}\text { Caroten } \\
\text { oids }\end{array}$ \\
\hline$\overline{\mathrm{NAA}_{0}}$ & 0.36 & 0.59 & 2.11 & $0.31 \mathrm{a}$ & 0.41 & $1.78 \mathrm{a}$ & 0.13 & 0.27 & 1.70 \\
\hline $\mathrm{NAA}_{10}$ & 0.37 & 0.59 & 2.10 & $0.21 \mathrm{~b}$ & 0.34 & $1.73 \mathrm{a}$ & 0.12 & 0.23 & 1.66 \\
\hline $\mathrm{NAA}_{100}$ & 0.39 & 0.62 & 2.20 & $0.10 \mathrm{c}$ & 0.19 & $1.53 \mathrm{~b}$ & 0.12 & 0.24 & 1.69 \\
\hline CV (\%) & 3.80 & 5.50 & 3.80 & 4.51 & 13.40 & 3.25 & 12.30 & 5.92 & 10.70 \\
\hline $\operatorname{LSD}(0.05)$ & NS & NS & NS & 0.05 & NS & 0.08 & NS & NS & NS \\
\hline
\end{tabular}

Mean in a vertical column followed by same letter do not differ significantly at $5 \%$ level.

Significant variations were observed in case of chlorophyll a content due to both the treatments and carotenoids content due to $\mathrm{NAA}_{200}$ treatment only at flowering stage. 
Foliar spray of NAA had beneficial effect on the number of tillers per plant, number of leaves per plants, chlorophyll content of leaves and grain yield in rice plants (Chaudhuri et al. 1980). Improved chlorophyll content with NAA spray of leaves were also reported on wheat and barley (Singh and Gill 1985, Orsi and Tallarico 1983). Akter (2010) also reported increased chlorophyll a content of leaves in maize due to both $\mathrm{NAA}_{100}$ and $\mathrm{NAA}_{200}$ applications, whereas, chlorophyll $\mathrm{b}$ and carotenoids contents of leaves increased due to $\mathrm{NAA}_{200}$ and decreased due to $\mathrm{NAA}_{100}$.

Results of the present investigation indicated that protein content of leaf increased significantly following $\mathrm{NAA}_{100}$ treatment in BRRI dhan 29 at the tillering and flowering stages, whereas, at grain filling stage protein content of leaf increased due to both the treatments but, was insignificant. In the variety BRRI dhan 50 , protein content of leaf increased at flowering and grain filling stage and decreased at tillering stage following both the treatments. Increase in protein content of leaf was significant only at grain filling stage due to $\mathrm{NAA}_{200}$ treatment (Table 3). Results also indicated that in both the varieties there is a decrease in protein content of leaf from the tillering stage to grain filling stage. The reduction of protein content from the tillering to the grain filling stage suggested diversion of more amino acids for carbohydrate metabolism during grain filling stage. The present findings corroborates with the findings of Akter (2010) who reported increased protein content in maize leaf due to application of 100 and $200 \mathrm{ppm}$ NAA.

Table 3. Effect of NAA on protein content of leaf ( $\mathrm{mg} / \mathrm{g}$ fresh weight) of two varieties of rice.

\begin{tabular}{|c|c|c|c|c|c|c|}
\hline \multirow[b]{2}{*}{ Treatment } & \multicolumn{3}{|c|}{ BRRI dhan 29} & \multicolumn{3}{|c|}{ BRRI dhan 50} \\
\hline & $\begin{array}{c}\text { Tillering } \\
(72 \\
\text { days })\end{array}$ & $\begin{array}{l}\text { Flowering } \\
\text { (95 days) }\end{array}$ & $\begin{array}{l}\text { Grain } \\
\text { filling } \\
(118 \\
\text { days }) \\
\end{array}$ & $\begin{array}{c}\text { Tillering } \\
\text { (72 } \\
\text { days) }\end{array}$ & $\begin{array}{c}\text { Flowering } \\
\text { (95 days) }\end{array}$ & $\begin{array}{r}\text { Grain } \\
\text { filling } \\
(118 \\
\text { days) }\end{array}$ \\
\hline \multicolumn{7}{|l|}{$\mathrm{NAA}_{0}$} \\
\hline & $18.67 \mathrm{~b}$ & $15.50 \mathrm{~b}$ & 16.73 & 23.00 & 20.50 & $17.23 \mathrm{~b}$ \\
\hline $\mathrm{NAA}_{100}$ & $23.17 \mathrm{a}$ & $19.50 \mathrm{a}$ & 17.12 & 20.17 & 22.67 & $18.40 \mathrm{~b}$ \\
\hline $\mathrm{NAA}_{100}$ & $20.33 \mathrm{~b}$ & $15.50 \mathrm{~b}$ & 17.27 & 20.50 & 22.00 & $19.63 \mathrm{a}$ \\
\hline CV (\%) & 10.60 & 12.70 & 3.20 & 10.90 & 6.40 & 6.10 \\
\hline $\operatorname{LSD}(0.05)$ & 2.27 & 2.36 & NS & NS & NS & 1.21 \\
\hline
\end{tabular}

Mean in a vertical column followed by same letter do not differ significantly at $5 \%$ level.

Table 4 showed that carbohydrate, protein, fat and energy content of grain increased due to both the treatments in both the varieties where, treatments mean varied significantly in case of protein and fat content. This indicates the stimulating effect of NAA in improving the quality of rice grain. The highest carbohydrate, protein, fat and energy content of grain was recorded from $\mathrm{NAA}_{100}$ treatment in both the varieties. Following $\mathrm{NAA}_{200}$ treatment, carbohydrate content of grain increased by $0.69 \%$ and $0.60 \%$ in BRRI dhan 
29 and BRRI dhan 50 respectively. Akter (2010) reported increase in carbohydrate content of grain due to both 100 and $200 \mathrm{ppm}$ of NAA application in maize. In case of BRRI dhan 29 , the increase in protein content of grain due to $\mathrm{NAA}_{100}$ was $15.68 \%$ over the control whereas, in BRRI dhan 50 , it was $9.89 \%$. Increases in protein content of grain due to application of NAA were reported on different plants viz. bitter gourd (Jahan et al. 1992), maize (Akter 2010).

Table 4. Effect of NAA on carbohydrate, protein, fat, ash, moisture and energy content of two varieties of rice grain.

\begin{tabular}{llccccccc}
\hline Variety & \multicolumn{1}{c}{ Treatments } & Carbohydrate & Protein & Fat & Ash & Moisture & Energy \\
\cline { 2 - 8 } & NAA $_{0}$ & 75.72 & $7.27 \mathrm{bc}$ & $0.40 \mathrm{c}$ & $2.70 \mathrm{a}$ & 13.91 & 343.98 \\
\multirow{3}{*}{ BRRI dhan 29 } & NAA $_{100}$ & 76.24 & $8.41 \mathrm{a}$ & $0.53 \mathrm{ab}$ & $1.20 \mathrm{~d}$ & 13.62 & 351.99 \\
& NAA $_{200}$ & 76.11 & $7.62 \mathrm{~b}$ & $0.45 \mathrm{bc}$ & $2.0 \mathrm{c}$ & 13.82 & 347.48 \\
\hline \multirow{3}{*}{ BRRI dhan 50 } & NAA $_{0}$ & 76.13 & $7.18 \mathrm{bc}$ & $0.42 \mathrm{bc}$ & $2.57 \mathrm{a}$ & 13.70 & 345.48 \\
& NAA $_{100}$ & 76.59 & $7.89 \mathrm{ab}$ & $0.61 \mathrm{a}$ & $2.06 \mathrm{c}$ & 12.85 & 352.04 \\
& NAA $_{200}$ & 76.49 & $7.43 \mathrm{~b}$ & $0.49 \mathrm{ac}$ & $2.39 \mathrm{~b}$ & 13.23 & 348.63 \\
& LSD(0.05) & NS & 0.55 & 0.12 & 0.17 & NS & NS \\
\hline
\end{tabular}

Mean in a vertical column followed by same letter do not differ significantly at $5 \%$ level.

Fat content of grain increased by $32.50 \%$ in BRRI dhan 29 and $45.24 \%$ in BRRI dhan 50 due to $\mathrm{NAA}_{100}$ treatment. Both increase and decrease in fat content of chick pea grain was observed depending on the concentrations of NAA (Karim et al. 2006). In both the varieties ash and moisture content of grain reduced following both the treatments where, significantly highest values were recorded from control in both the varieties. The lowest ash content of grain was obtained from $\mathrm{NAA}_{100}$ and it was $55.56 \%$ and $19.84 \%$ lower than the control in BRRI dhan 29 and BRRI dhan 50 respectively. However, ash content of maize grain was not affected by 100 and 200 NAA application (Akter 2010). Moisture content of grain decreased by 0.65 and $2.08 \%$ in BRRI dhan 29 and 6.20 and $3.43 \%$ in $\mathrm{BRRI}$ dhan 50 due to $\mathrm{NAA}_{100}$ and $\mathrm{NAA}_{200}$ treatments respectively. Similar trend was also obtained in maize grain following NAA treatments (Akter 2010).

Thus, results indicate that, in both the varieties of rice, out of two treatments of NAA, $100 \mathrm{ppm}$ produced better stimulations. The results are also consistent with the view that plant growth regulators at different concentration can have quite different effect in different plants and sometimes the same plant growth regulator at identical concentration can have different effects on various organs of the same plant (Ridge 1991). Moreover, two varieties of rice responded differently. Environmental conditions prevailing during the growth and development of plants are also important determining factors. 


\section{References}

Adam, A. M. M. G. and N. Jahan. 2011. Effects of naphthalene acetic acid on yield attributes and yield of two varieties of rice (Oryza sativa L.). Bangladesh J. Bot. 40(1): 97-100.

Adam, A. M. M. G., N. Jahan and S. Hoque. 2012. Effects of naphthalene acetic acid on nutrient uptake by two varieties of rice (Oryza sativa L.). Dhaka Univ. J. Biol. Sci. 21(1): 9-16.

Akter, R. 2010. Effect of Naphthalene acetic acid (NAA) on growth, physiological and biochemical responses and yield attributes of maize (Zea mays L. var. Pacific 283). M.S. Thesis. Department of Botany, University of Dhaka. 81pp.

Anonymous. 1976. A Manual of Laboratory techniques. National Institute of Nutrition. Indian Council of Medical Research, Hyderabad-50007, India, pp. 1-5.

Chaudhuri, D., P. Basuchaudhuri and D. K. D. Gupta. 1980. Effect of growth substances on growth and yield of rice. Indian Agriculturist. 24: 169-175.

FAO. 1993. In: Rice in Human Nutrition. B.O. Juliano. 162 pp.

Fertilizer Recommendation Guide. 2005. Published by Bangladesh Agriculture Research Council.

Jahan, N. and A. M. M. G. Adam. 2011. Comparative growth analysis of two varieties of rice following naphthalene acetic acid application. J. Bangladesh Acad. Sci. 35(1): 113-120.

Jahan, N., Q. A. Fattah and M. K. Roy. 1992. Effect of NAA and IBA on some biochemical component of bitter gourd. Bangladesh J. Sci. Res. 10(1): 37-41.

Karim, M. F., Q. A. Fattah and A. B. M. Khaleduzzaman. 2006. Changes in biocomponent of chickpea (Cicer arietinum L.) sprayed with Potassium naphthenate and Naphthalene acetic acid. Bangladesh J. Bot. 35(1): 39-43.

Lowry, O. H., N. J. Rosebrough, A. L. Farr and R. J. Randall. 1951. Protein measurement with folin phenol reagent. J. Boil. Chem. 193: 265-275.

Maclachalan, S. and S. Zalik. 1963. Plastid structure, chlorophyll concentration and free amino acid composition of a chlorophyll mutant of barley. Can. J. Bot. 41: 1053-1062.

Mckinney, G. 1940. Criteria for purity of chlorophyll preparations. J. Biol. Chem. 132: 91-107.

Muthukumar, V. B., K. Velayudham and N. Thavaprakaash. 2005. Growth and yield of baby corn (Zea mays L.) as influenced by PGRs and different time of nitrogen application. Res. J. Agric. Biol. Sci. 1(4): 303-307.

Orsi, S. and R. Tallarico. 1983. Use of plant growth regulators and biostimulants in wheat and barley. Informators Agario. 39: 27539-41.

Purseglove, J. W. 1975. Tropical crops. Monocotyledons. Vol. 1 and 2 combined. Longman group Ltd. London. pp. 161-198.

Ridge, I. 1991. Plant cells and growth. In: plant physiology. The Open University, Hodder and Stoghton. U.K. pp. 225-281.

Singh, H. and H. S. Gill. 1985. Effect of foliar spray of NAA on the growth and yield of late sown wheat and barley. Indian J. Eco. 12:267-272.

Steel, R. G. D. and J. H. Torrie. 1960. Principles and Procedures of statistics. McGraw- Hill, New York. pp. 480-482.

von Wettstein, D. 1957. Chlorophyll-lethal under Submikroskopisoche Formechse der Plastiden. Expt. Cell Res. 12: 427-507.

(Received revised manuscript on 30 November 2014) 